\title{
非荷重ならびに再荷重に伴う骨応答と等尺性抵抗運動の影響
}

\author{
山内秀樹*1 河井宏之*2 益子詔次*3 \\ 木村真規*4 宮野佐年*1 米本 恭三*5
}

\section{Bone Responses to Mechanical Unloading and Reloading With or Without Isometric Resistance Exercise}

\author{
Hideki Yamauchi, ${ }^{* 1}$ Hiroyuki KawaI, ${ }^{* 2}$ Shoji Mashiko, ${ }^{* 3}$ \\ Masaki Kimura, ${ }^{* 4}$ Satoshi Miyano, ${ }^{* 1}$ Kyozo Yonemoto*5
}

\begin{abstract}
Non-weight-bearing associated with a microgravity environment or bed rest induces musculoskeletal atrophy. It takes a longer time to restore bone mass than skeletal muscle mass. The purpose of the present study was to investigate whether isometric resistance exercise (IRE) can attenuate loss of bone mass during unloading and accelerate its recovery during reloading. Twenty-six Fischer 344 female rats (aged 16 weeks) had their hindlimbs suspended for 3 weeks (unloading); 12 of these rats were allowed subsequent cage activity (reloading) for 3 weeks with or without IRE. IRE (stationary support on a cylindrical grid inclined 60 or 80 degrees) was done for $30 \mathrm{~min} /$ day, 6 days/week, with an additional load of $30 \%$ or $50 \%$ body mass attached to the tail during the unloading and reloading periods. The femurs from four experimental and two age-matched control rats were evaluated with dual-energy X-ray absorptiometry, mechanical testing, and fat-free dry mass (FFDM) measurement. Bone mineral density (BMD) was measured in the whole femur and in 7 regions divided equally along the long axis of the epiphysis from proximal (R 1) to distal (R 7). After unloading, FFDM, bone mineral content (BMC), and BMD of the whole tibia decreased by $6.3 \%, 8.7 \%$, and $6.0 \%$, respectively. FFDM and BMC, but not $\mathrm{BMD}$, returned to the levels of age-matched controls during reloading. Unloadinginduced decreases in BMD were observed in each of the 7 evenly divided regions. The rate of decrease in BMD was region-dependent and was pronounced in the epiphysis and the metaphysis compared to the diaphysis. The BMD in $\mathrm{R} 4, \mathrm{R} 6$, and $\mathrm{R} 7$ remained less than that in the age-matched controls after reloading. No significant changes were observed in maximum breaking load, energy, and deformation after unloading and reloading. IRE showed no effects on bone loss after unloading and reloading. We concluded that 1) regional variations in bone responses to skeletal unloading exist, and 2) a longer time than the unloading period is required for recovery from osteopenia. Further studies are needed to develop more effective countermeasures against osteopenia and to aid its recovery. (Jpn J Rehabil Med 2003; 40 : 41-48)
\end{abstract}

2002 年 6 月 17 日受付, 2002 年 12 月 5 日受理

*1 東京慈恵会医科大学リハビリテーション医学講座体力医学研究室/\% 182-8570 東京都調布市国領町 8-3-1

Division of Physical Fitness, Department of Rehabilitation Medicine, Jikei University School of Medicine

*2 国立療養所東宇都宮病院リハビリテーション科/テ 329-1193 栃木県河内郡河内町下岡本 2160

Department of Rehabilitation, National Higashi-Utsunomiya Hospital

*3 宇都宮大学教育学部/ $321-8505$ 杤木県宇都宮市峰町 350

Faculty of Education, Utsunomiya University

*4 共立薬科大学薬物治療学講座/ 7 105-8512 東京都港区芝公園 1-5-30

Laboratory of Pharmaceutical Therapeutics, Kyoritsu College of Pharmacy

*5 東京都立保健科学大学/ $116-8551$ 東京都荒川区東尾久 7-2-10

Tokyo Metropolitan University of Health Sciences 
要 旨：若年ラットを用い，非荷重と再荷重に伴う骨応答と等尺性抵抗運動の影響を検討し た。 3 週間の非荷重によりDXA 法によって評価した大腿骨全体の骨密度は $6 \%$ の低下（ $p<$ 0.05）を示した．長軸方向に 7 等分した領域別に骨密度を比較した結果，すべての領域で非荷 重による骨密度の低下を認めたが，その低下率は骨幹部より骨端部や骨幹端部で顕著であっ た。低下した骨密度は 3 週間の再荷重により回復傾向を認めたが，骨全体で対照群に比べ $3.4 \%$ 低值（ $p<0.05 ）$ であった。再荷重後の骨密度の低值は骨幹部と遠位骨幹端及び骨端部 において観察された。骨 $1 / 2$ 部位におりる最大破断荷重, エネルギー, 変形量に非荷重や再荷 重の影響はみられなかった。非荷重ならびに再荷重期間に負荷した等尺性抵抗運動はいずれの 評価項目においても，骨量低下やその回復に対する有用性は確認されなかった。運動負荷が副 腎重量を増加させた結果から，グルココルチコイドによる骨量低下作用が一部関係している可 能性が考えられた。以上の成績は，非荷重による骨密度低下は部位特異的であること，非荷重 によって低下した骨密度の再荷重後の完全な回復には長期を要することを示唆する. 効果的な 対処法の確立には，今後も更なる検討が必要である.（リ八医学 $2003 ； 40 ： 41-48$ )

Key words : 非荷重 (unloading), 再荷重 (reloading), 骨密度 (bone mineral density), 機械的特性（mechanical property），等尺性運動（isometric exercise）

\section{はじめに}

長期安静臥床など，非荷重状態に関連した骨に対す る荷重負荷の減少は骨量低下を引き起こす。この骨量 低下は，日常活動において，体重による荷重負荷が加 わる支持骨に認められるもので，必ずしも全身性の変 化ではないことが報告されている1 3). 体重支持骨に おける骨量低下は再荷重に伴い回復するが，筋量に比 べて骨量回復は遷延すること出が報告されている。ど の骨に，またどの部位において非荷重の影響が大きい のか, また，再荷重後，どの程度の期間で骨量が回復 するのかを検討することは，日常生活へ復帰した際の 生活活動に対する注意や訓練処方作成のための基礎的 資料となり,リハビリテーション医学的に重要である と考えられる.

適度な運動負荷は骨量を増加させる。この運動によ る骨量増加効果も非荷重に伴う骨応答と同様, 荷重負 荷の増大した骨に対して認められること5) が報告され ている.したがって, 荷重条件の変化に対する骨応答 は Frostのメカノスタット理論6)に基づいた局所性変 化であると考えられる，つまり，力学的ストレスが負 荷された骨においては骨形成が促進され，骨量が増加 するが，逆に力学的ストレスが減少した場合，骨吸収 が促進され，骨量が低下寸る．このような観点から考 えると，非荷重による骨量低下が著しい体重支持骨に 荷重負荷を加えることが，非荷重による骨量低下防止 ならびに再荷重による骨量回復促進に対して，有効な 手段となりうるものと推察される.

非荷重状態は骨虚弱化だけでなく, 骨格筋機能も減 退させることから，筋骨格系の機能低下を軽減するた
めには，筋骨格系に対する肥大効果の高い抵抗運動が 効果的である7) と考えられる. 先行研究8,9)において, 実験的非荷重状態で飼育した実験動物の筋機能低下や その回復に対し，等尺性抵抗運動の効果が示されてい るが，骨量低下やその回復に対する影響に関しては明 らかでない.

そこで, 本研究では, 先行研究8,9) と同一動物の大 腿骨を用い, 非荷重に伴う骨量低下とその回復に対す る等尺性抵抗運動の影響について検討した。

\section{実験方法}

\section{1. 対象と飼育条件}

実験には(株) 日本エスエルシーから 6 週齢で購入し た Fischer 344 系雌ラット 38 匹を用いた。 16 週齢時 に各群の平均体重が等しくなるように, 以下の 6 群に グルーピングした.

(1)懸垂群 $(n=7): 16$ 週齢から尾部懸垂により後肢非 荷重状態で 3 週間飼育. 19 週齢で解剖.

(2)懸垂運動群 $(n=7): 16$ 週齢から尾部懸垂により後 肢非荷重状態で 3 週間飼育, 懸垂期間中に運動負荷 を実施. 19 週齢で解剖。

(3)懸垂対照群 $(n=6)$ : 懸垂群と懸垂運動群の週齢の 一致した対照群, 19 週齢で解剖.

(4)回復群 $(n=6): 16$ 週龄から尾部懸垂により後肢非 荷重状態で 3 週間飼育後, 懸垂解除し, 3 週間通常 飼育 (再荷重). 22 週齢で解剖.

(5)回復運動群 $(n=6): 16$ 週歯から尾部懸垂により後 肢非荷重状態で 3 週間飼育後, 懸垂解除し， 3 週間 通常飼育 (再荷重). 再荷重期間に運動負荷を実施. 22 週齢で解剖. 
6)回復対照群 $(n=6)$ : 回復群と回復運動群の週齢の 一致した対照群, 22 週齢で解剖。

(1)～(3)群の比較により，非荷重に伴う骨応答と運動 の影響について，また，(4)〜(6)群の比較により，再荷 重に伴う骨応答と運動の影響について検討した。実験 期間中の摂水は自由摂取としたが，固型飼料（MM3 ，船橋農場）は各群の攝餌量が同一になるように調 整，飼育した。なお，本実験の遂行にあたり，日本生 理学会の制定した「生理学領域における動物実験に関 する基本的指針」を遵守した。

\section{2. 運動負荷方法}

懸垂運動群と回復運動群には 1 日 1 回，30 分間, 週 6 日の頻度で，後肢筋の等尺性収縮を主体とした抵 抗運動8,9) を実施した（図 1)。この運動は半筒状にし た金網（長さ $45 \mathrm{~cm}$ ，最大径 $6.5 \mathrm{~cm}$ ）の床面上で， 支持するもので，下肢骨への荷重負荷強度は，金網の 傾斜角度，動物の自重と尾部につけられた鍾により調 節した。懸垂運動群の運動条件は，1 週目は傾斜角度

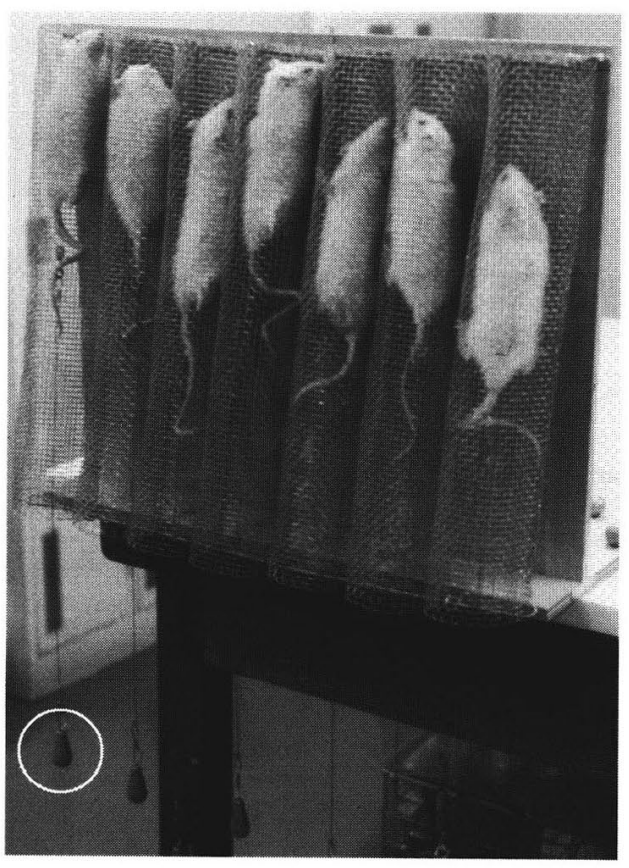

図 1 ラットの等尺性抵抗運動

ラットは半筒状にした金網（長さ $45 \mathrm{~cm}$, 最大径 6.5 $\mathrm{cm})$ の平らな床面上で懸垂・維持している。一度, 運動 装置内にラットを入れると,ラットはほとんど昇降運動は 行わず, 一定の位置で維持している。負荷強度は金網の傾 斜角度とラットの尾部につけた錪により調節した。金網の 傾斜角度は 60 ないしは 80 度，鍾（図中の丸）は体重の 30\%ないしは $50 \%$ とした。
80 度，鍾をつけない条件で 30 分間とし，2 週目以降 は傾斜角度 60 度，鍾をつけない条件で 3 分間十傾斜 角度 80 度，体重の約 $30 \%$ の鍾をつけた条件で 2 分間 を 1 セット（計 5 分間）とし，6セット繰り返し行っ た。回復運動群の運動条件は, 傾斜角度は 80 度とし, 1 週目は錘をつけない条件で 30 分間， 2 週目は鍾をつ けない条件で 3 分間十体重の約 $30 \%$ の錘をつけた状 態で 3 分間を 1 セット（計 6 分間）とし， 5 セット繰 り返し行った。3 週目は錘を体重の約 50\%とし，他の 条件は 2 週目と同様とした。

\section{3. 実験手順}

実験週齢にて，体重測定後，ネンブタール過投与に より動物を安楽死させ，副腎と大腿骨を摘出した。副 腎は直ちに湿重量を測定し，ストレスの指標として用 いた ${ }^{10)}$ 。大腿骨は右側は骨密度測定用に $75 \%$ エ夕ノ ール中で固定し, 左側は静的 3 点曲げ試験用に一 $20^{\circ} \mathrm{C}$ フリーザー内で保存した。

\section{4. 骨密度測定}

Hologic 社製の QDR-2000を用い，DXA 法で骨密 度を測定した。被検骨を水深 $1.5 \mathrm{~cm}$ の脱イオン水中 におき，小動物摘出骨用の超高分解能モードでスキャ ンした。スキャンされた画像から，骨全体の面積，骨

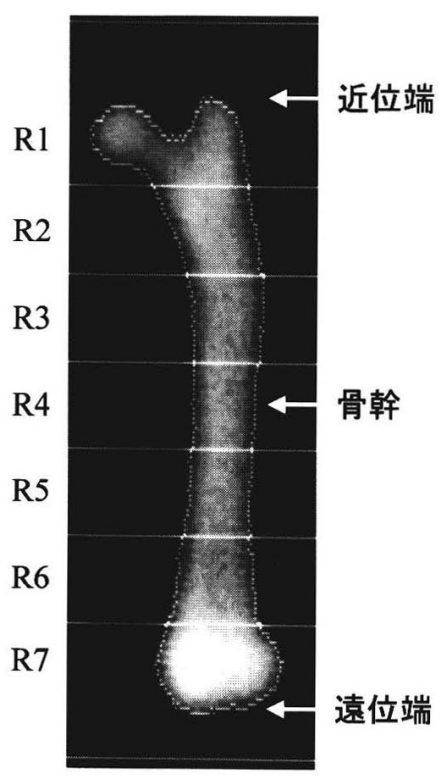

図 2 DXA 法による大腿骨のスキャン画像と分析 領域

Hologic QDR-2000により，摘出大腿骨を超高解像度モー ド $(0.254 \times 0.127 \mathrm{~mm})$ でスキャンし, 骨全体と長軸に沿 って 7 等分した各領域（R 1 R R ）の骨密度を算出した。 
塩量, 骨密度（面積あたりの骨塩量）を算出した。ま た，長軸方向に 7 等分した領域別に骨密度を算出した (図 2). 骨長を測定した後, クロロホルムとメタノー ルの $2: 1$ 混合液中に 1 週間浸し, $120^{\circ} \mathrm{Cで} 6$ 時間加熱 乾燥後, 脱脂乾燥骨重量を求めた.

\section{5. 静的 3 点曲げ試験}

凍結保存された左側骨を周囲の軟部組織を取り除 き，骨長を測定した。骨 $1 / 2$ 部位の長径と短径をキャ リパーで測定した後に，静的 3 点曲げ試験（RX-160, 飯尾電気）を実施した。その際，プランジャーが後面 から前面へ力が加わるように，また，プランジャーが 骨の $1 / 2$ 部位にあたるように注意深く骨を支持台に置

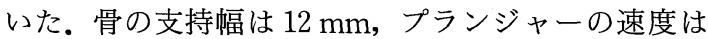
$10 \mathrm{~mm} / \mathrm{min}$ の条件下で骨が破断されるまでの最大荷 重，エネルギー量，変形量を算出した。

\section{6. 統計処理}

各群の值は平均值士標準偏差で示した．各群の平均 値の差の検定は Bartlett 検定により分散の均一性を 確認し，一元配置分散分析を行い，有意であった項目 については, Tukey-Kramer の多重比較を行った。 いずれも危険率 $5 \%$ をもって有意とした。

\section{実 験成 績}

\section{1. 体重と副腎重量の変化}

各群の体重と副腎重量を図 3 に示した。懸垂群と懸 垂運動群の体重は懸垂対照群に比べ，それぞれ 10.6 , $12.0 \%$ の有意な低值を示した。回復群と回復運動群の
体重は回復対照群に比べ 5.7\%，11.7\%の有意な低值 を示した。また，回復群と回復運動群間においても体 重に有意差がみられた。

懸垂群と懸垂対照群の副腎重量に差は認められなか ったが，懸垂運動群の副腎重量は懸垂対照群と懸垂群 に比べて高值を示した。また，回復群と回復対照群の 副腎重量に差は認められなかったが，回復運動群の副 腎重量は回復対照群と回復群に比べて高值を示した。 体重 $100 \mathrm{~g}$ あたりの副腎重量に関して，懸垂対照群， 懸垂群，懸垂運動群のいずれの群間においても差を認 めた。また，回復対照群，回復群，回復運動群のいず れの群間においても差を認めた。

\section{2. 非荷重による大腿骨の変化}

表 1 に 3 週間の非荷重による大腿骨の変化を示し た。懸垂対照群，懸垂群，䀣垂運動群間で骨長に差は 認められなかった，脱脂乾燥重量において，懸垂群は 懸垂対照群に比べ低值を示したが，懸垂運動群と懸垂 対照群間では差を認めなかった。

DXA による骨投影面積は 3 群間で差がみられなか った。懸垂群の骨全体の骨塩量，骨密度，骨塩量の乾 燥重量比は懸垂対照群に比べ低值を示した。一方，懸 垂運動群では，懸垂対照群に比べ骨全体の骨塩量では 差がみられなかったが，骨密度と骨塩量の乾燥重量比 の低值が観察された。

領域別骨密度の比較では，懸垂対照群に比べて，懸 垂群の骨密度は測定した 7 領域すべてにおいて低值を 認めた. 懸垂運動群では R 3 と R 5 以外の領域におい
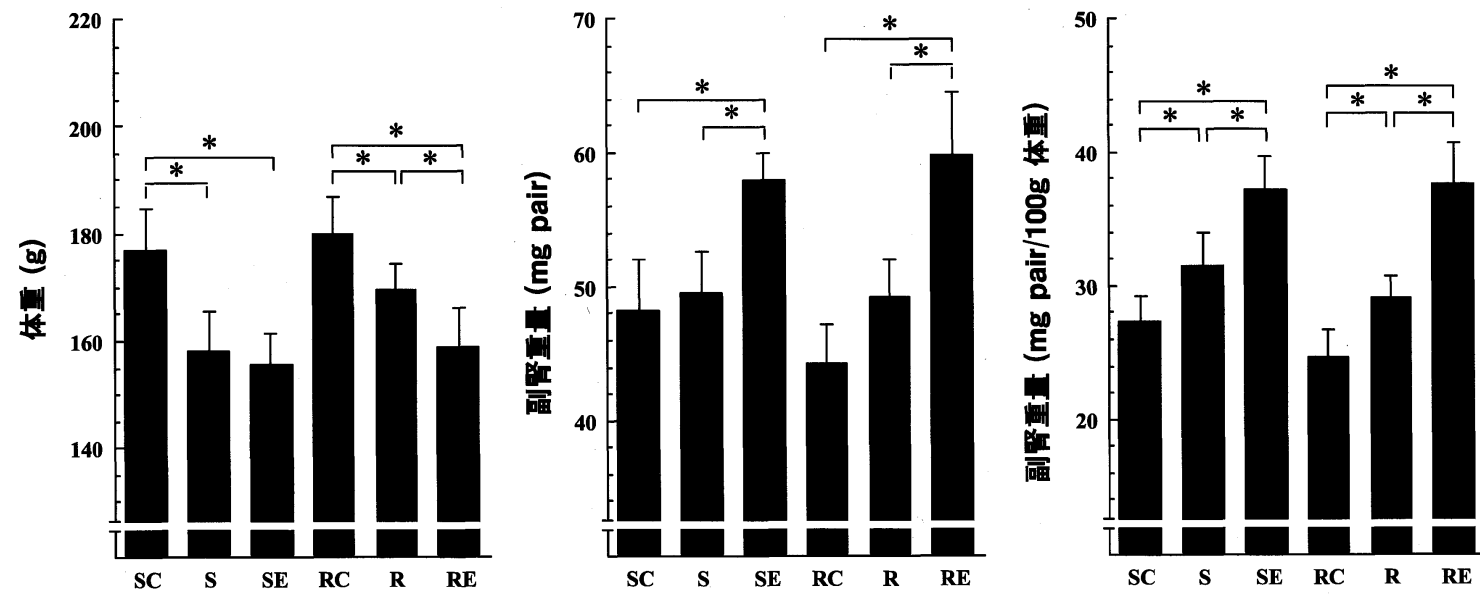

図 3 ·体重, 副腎重量, 体重あたりの副腎重量の比較

$\mathrm{SC}$ : 懸垂対照群, $\mathrm{S}$ ：懸垂群, $\mathrm{SE}$ : 懸垂運動群, $\mathrm{RC}$ ：回復対照群, $\mathrm{R}$ ：回復群, $\mathrm{RE}$ ：回復運動群. *は Tukey-Kramer の多重比較による群間の有意差 $(p<0.05)$ を示す. 
表 1 非荷重に伴う骨応答と等尺性抵抗運動の影響

\begin{tabular}{|c|c|c|c|c|c|}
\hline & 懸垂対照群（ $n=5 ）$ & 懸垂群 $(n=6)$ & $\% \Delta$ & 懸垂運動群 $(n=5)$ & $\% \Delta$ \\
\hline \multicolumn{6}{|l|}{ 骨全体の特徵 } \\
\hline 骨長，mm & $32.3 \pm 0.5$ & $32.3 \pm 0.3$ & 0.0 & $32.4 \pm 0.4$ & 0.3 \\
\hline 脱脂乾燥重量, mg & $351.5 \pm 18.7$ & $329.4 \pm 11.5^{*}$ & -6.3 & $333.0 \pm 10.3$ & -5.3 \\
\hline 投影面積, $\mathrm{cm}^{2}$ & $1.309 \pm 0.047$ & $1.271 \pm 0.026$ & -2.9 & $1.281 \pm 0.024$ & -2.2 \\
\hline 骨塩量, mg & $248.2 \pm 14.6$ & $226.6 \pm 9.7^{*}$ & -8.7 & $229.7 \pm 8.5$ & -7.5 \\
\hline 骨密度, $\mathrm{mg} / \mathrm{cm}^{2}$ & $189.5 \pm 4.4$ & $178.2 \pm 4.6^{*}$ & -6.0 & $179.3 \pm 3.6^{*}$ & -5.4 \\
\hline 骨塩量/脱脂乾燥重量, mg\% & $70.6 \pm 0.6$ & $68.8 \pm 0.9^{*}$ & -2.5 & $69.0 \pm 0.6^{*}$ & -2.3 \\
\hline \multicolumn{6}{|l|}{ 各領域の骨密度 } \\
\hline R 1 & $177.4 \pm 6.1$ & $165.5 \pm 3.9^{*}$ & -6.7 & $164.5 \pm 6.2^{*}$ & -7.3 \\
\hline R 2 & $202.5 \pm 4.1$ & $192.5 \pm 5.1^{*}$ & -4.9 & $194.4 \pm 4.5^{*}$ & -4.0 \\
\hline R 3 & $177.6 \pm 5.0$ & $171.3 \pm 3.4^{*}$ & -3.6 & $172.7 \pm 2.3$ & -2.8 \\
\hline R 4 & $172.3 \pm 3.1$ & $166.8 \pm 1.4^{*}$ & -3.2 & $166.4 \pm 2.6^{*}$ & -3.4 \\
\hline R 5 & $161.8 \pm 4.8$ & $156.7 \pm 1.7^{*}$ & -3.1 & $157.4 \pm 1.7$ & -2.7 \\
\hline R 6 & $167.1 \pm 5.3$ & $156.2 \pm 7.2^{*}$ & -6.5 & $154.8 \pm 5.7^{*}$ & -7.3 \\
\hline R 7 & $241.4 \pm 4.2$ & $220.8 \pm 12.5^{*}$ & -8.5 & $221.5 \pm 8.6^{*}$ & -8.2 \\
\hline 骨幹部の破断試験結果と形態 & $(n=6)$ & $(n=7)$ & & $(n=7)$ & \\
\hline 最大破断荷重, N & $123.6 \pm 9.0$ & $113.5 \pm 8.2$ & -8.1 & $112.6 \pm 8.3$ & -8.8 \\
\hline 最大破断エネルギー, J $\left[\times 10^{-2}\right]$ & $3.04 \pm 0.29$ & $2.63 \pm 0.39$ & -13.5 & $2.60 \pm 0.43$ & -14.3 \\
\hline 破断変形, mm & $0.41 \pm 0.02$ & $0.41 \pm 0.06$ & 0.0 & $0.38 \pm 0.04$ & -7.3 \\
\hline 長径, mm & $2.85 \pm 0.09$ & $2.79 \pm 0.05$ & -2.1 & $2.81 \pm 0.05$ & -1.4 \\
\hline 短径, mm & $2.60 \pm 0.04$ & $2.58 \pm 0.09$ & -0.8 & $2.58 \pm 0.07$ & -0.8 \\
\hline
\end{tabular}

平均土標準偏差. ${ }^{*}$ Tukey-Kramer の多重比較による懸垂対照群との有意差（ $p<0.05 ）$ を示す. \% $\Delta$ は懸垂対照群を 基準とした変化率.

て，懸垂対照群に比べ低值を認めた。

骨 $1 / 2$ 部位における最大破断荷重，エネルギー量， 変形量は，3 群間で差を認めなかった。また，長径と 短径においても 3 群間で差を認めなかった。

すべての指標において，懸垂群と懸垂運動群間に差 を認めなかった。

\section{3. 再荷重による大腿骨の変化}

表 2 に非荷重解除後の再荷重 3 週間後の大腿骨の変 化を示した。骨長，脱脂乾燥重量，骨全体の投影面 積，骨塩量では 3 群間で差を認めなかった，回復群と 回復運動群の骨全体の骨密度方骨塩量の乾燥重量比は 回復対照群に比べ低值を示した。

領域別の骨密度では回復対照群に比べ回復群では R 4，R 6，R 7 において，回復運動群では R 2 を除く すべての領域で骨密度の低值が認められた。

回復群の骨 $1 / 2$ 部位における最大破断荷重，エネル ギー量は回復対照群と差を認めなかったが，回復運動 群は回復対照群に比べ低值を示した。また，変形量， 長径，短径は 3 群間で差がみられなかった。

回復群と回復運動群間では, すべての指標において 差を認めなかった。

\section{考察}

\section{1. 非荷重による骨量低下}

骨への荷重負荷減少に起因する骨量低下は骨吸収の 急激な増加と骨形成の持続的な減少により生じる ${ }^{11,12)}$ が，この骨量低下は骨全体で一様ではなく, 部位特異 性が先行研究13 15)により示されている. 本研究にお いて，非荷重による骨密度低下は 7 領域すべてにおい て観察されたが，骨幹部に比べ骨端部や骨幹端部で顕 著であった結果は先行研究を支持する。これらの領域 において骨密度低下が顕著な結果には, 関節固定, 除 神経, 無重力環境など, 骨に対する荷重負荷が減少す る場合，皮質骨に比べ海綿骨量の低下が影著に起こる こと ${ }^{16)}$ に起因していると考えられる.

Matsumoto ら ${ }^{14)}$ は 2 週間の後肢懸垂により，骨密 度と皮質骨面積の低下を認めたラット大腿骨骨幹部に おいて，骨内膜では石灰化速度に変化はみられなかっ たが，骨(外)膜では低下を認めている，我々の成績に おいても, 低下率は少ないものの, 皮質骨だけで構成 される骨幹部において骨密度低下が観察された結果 は，このような骨膜下骨形成の抑制に起因していると 推測される。しかしながら，骨 $1 / 2$ 部位での最大破断 
表 2 再荷重に伴う骨応答と等尺性抵抗運動の影響

\begin{tabular}{|c|c|c|c|c|c|}
\hline & 回復対照群 $(n=6)$ & 回復群 $(n=6)$ & $\% \Delta$ & 回復運動群 $(n=6)$ & $\% \Delta$ \\
\hline \multicolumn{6}{|l|}{ 骨全体の特徵 } \\
\hline 骨長, mm & $32.8 \pm 0.1$ & $33.1 \pm 0.4$ & 0.9 & $33.1 \pm 0.3$ & 0.9 \\
\hline 脱脂乾燥重量, mg & $378.6 \pm 9.0$ & $369.9 \pm 12.2$ & -2.3 & $363.5 \pm 17.4$ & -4.0 \\
\hline 投影面積, $\mathrm{cm}^{2}$ & $1.364 \pm 0.018$ & $1.356 \pm 0.037$ & -0.6 & $1.350 \pm 0.043$ & -1.0 \\
\hline 骨塩量, mg & $271.3 \pm 7.0$ & $260.7 \pm 10.7$ & -3.9 & $254.6 \pm 15.2$ & -6.1 \\
\hline 骨密度, $\mathrm{mg} / \mathrm{cm}^{2}$ & $198.8 \pm 3.6$ & $192.1 \pm 3.3^{*}$ & -3.4 & $188.5 \pm 5.7^{*}$ & -5.2 \\
\hline 骨塩量/脱脂乾燥重量, mg\% & $71.7 \pm 0.5$ & $70.5 \pm 0.9^{*}$ & -1.7 & $70.0 \pm 0.9^{*}$ & -2.4 \\
\hline \multicolumn{6}{|l|}{ 各領域の骨密度 } \\
\hline $\mathrm{R} 1$ & $186.3 \pm 3.1$ & $182.0 \pm 4.6$ & -2.3 & $179.5 \pm 4.8^{*}$ & -3.7 \\
\hline $\mathrm{R} 2$ & $211.6 \pm 5.0$ & $207.0 \pm 3.9$ & -2.1 & $203.4 \pm 9.1$ & -3.9 \\
\hline R 3 & $187.2 \pm 4.4$ & $181.5 \pm 3.5$ & -3.1 & $178.6 \pm 7.2^{*}$ & -4.6 \\
\hline R 4 & $182.5 \pm 2.4$ & $174.6 \pm 2.2^{*}$ & -4.3 & $172.4 \pm 5.2^{*}$ & -5.5 \\
\hline R 5 & $170.4 \pm 2.6$ & $165.1 \pm 2.4$ & -3.1 & $163.0 \pm 5.1^{*}$ & -4.3 \\
\hline R 6 & $173.8 \pm 6.6$ & $161.4 \pm 3.1^{*}$ & -7.1 & $156.5 \pm 5.0^{*}$ & -9.9 \\
\hline R 7 & $252.9 \pm 7.9$ & $240.9 \pm 5.7^{*}$ & -4.7 & $234.3 \pm 4.9^{*}$ & -7.4 \\
\hline 骨幹部の破断試験結果と形態 & & $(n=5)$ & & & \\
\hline 最大破断荷重, N & $130.7 \pm 6.3$ & $123.1 \pm 6.3$ & -5.8 & $118.3 \pm 7.9^{*}$ & -9.5 \\
\hline 最大破断エネルギー, J $\left[\times 10^{-2}\right]$ & $3.28 \pm 0.24$ & $2.86 \pm 0.31$ & -12.6 & $2.87 \pm 0.26^{*}$ & -12.4 \\
\hline 破断変形, mm & $0.42 \pm 0.02$ & $0.38 \pm 0.02$ & -9.5 & $0.41 \pm 0.04$ & -2.4 \\
\hline 長径, mm & $2.93 \pm 0.07$ & $2.88 \pm 0.11$ & -1.7 & $2.86 \pm 0.10$ & -2.4 \\
\hline 短径, $\mathrm{mm}$ & $2.67 \pm 0.07$ & $2.66 \pm 0.08$ & -0.4 & $2.67 \pm 0.05$ & 0.0 \\
\hline
\end{tabular}

平均土標準偏差. *Tukey-Kramer の多重比較による回復対照群との有意差（ $p<0.05 ）$ を示す％ \% は回復対照群を 基準とした変化率.

荷重やエネルギー量に変化がみられなかったのは，断 面形態特性の変化を認めなかったためと考えられる.

\section{2. 再荷重による骨量回復}

Vico ら ${ }^{3)}$ は，6 6 月齢の雄ラットを用い，14 日間 の後肢懸垂により，脛骨で $7.78 \%$ ，大腿骨で $5.98 \%$ の骨塩量の低下を認め,さらに，懸垂解除 28 日後に おいても, 骨塩量, 骨密度ともに対照群に比べ低值で あったと報告している. Sessions ら ${ }^{17)} は ， 14$ 日間の 後肢懸垂によりラット脛骨のカルシウム含量の $12.5 \%$ の低下を認め, 懸垂解除後の再荷重期間の延長 に伴い, カルシウム含量の回復を認めたが, 再荷重 14 日後も完全な回復が得られなかったことを報告し ている。さらに長期の非荷重による影響では, Thomaidis \& Lindholm ${ }^{18)}$ は 4 週間の関節固定後の骨 の完全な回復には 16 週間を要すること，また， Mattsson ${ }^{19)}$ は，16 週間の関節固定により低下した骨 量は, 固定解除後 48 週間でも完全な回復がみられな かったことを示している，本研究においても，非荷重 期間と同じ再荷重期間では対照群に比べ，骨密度の低 值が観察され，先行研究結果を支持する.

懸垂解除後の再荷重期間において，1 日あたりの骨 密度増加率は, 対照群 $\left(0.45 \mathrm{mg} / \mathrm{cm}^{2} /\right.$ day $)$ に比べ
回復群 $\left(0.66 \mathrm{mg} / \mathrm{cm}^{2} / \mathrm{day}\right)$ で高値を示した。この ような懸垂解除後の骨形成穴進は, 先行研究17,19,20) に おいても認められており，機能低下した骨が，再荷重 に対し必要とされる骨形態・機能を獲得するための適 応現象と考えられる。したがって，低下した骨密度 は，再荷重によりやがては対照レベルにまで回復する と思われるが，非荷重期間に対してどの程度の期間が 必要なのかについては明らかでない. Sessions ら ${ }^{17)}$ は，荷重期間とカルシウム含量の回帰から，再荷重後 カルシウム含量が対照レベルに回復するのは, 非荷重 期間の 3〜 4 倍の $6 \sim 8$ 週間を要すると推定している. しかしながら，加齢に伴い骨成長は低下するものの， 生涯を通じて骨の成長が認められるラットに比べ，七 トではさらに長期の再荷重を必要とする可能性が考え られる，ヒトと同様，骨格の成熟後に骨成長が停止す るサルを用いた Young ら ${ }^{21)}$ の報告によれば， 7 カ月 の関節固定では，正常な骨量回復に 3 年間を要するこ とが示されている。いずれにしても，再荷重後の骨の 完全な回復には，非荷重期間に対してかなりの長期を 必要とすると考えられるため, 再荷重後の回復期間に おいては，骨折の予防から転倒しないための十分な配 慮が必要であろうと思われる。 


\section{3. 抵抗運動の影響}

Rubin ${ }^{22)}$ は羊の後肢に低強度機械的刺激を 1 日 20 分間, 週 5 日, 12 力月にわたり負荷したところ, pQCT により評価した脛骨近位部における皮質骨密 度に変化はみられないが, 海綿骨密度の増加を認めて いる. Westerlind ら ${ }^{23)}$ は 6 週間のスクワット運動 (ウエイトジャケットを装着した状態で，17～19 セッ 卜を週 3 回負荷）の影響をラット脛骨において調べ, 皮質骨量の増加はみられなかったが，骨幹端部におけ る海綿骨量の増加（対照に比べ 2.2 倍）を認め,この 海綿骨量増加は走運動の効果に比べ顕著であると考察 している．このように，抵抗運動は皮質骨に比べて海 綿骨に対する骨量増加効果が高いことから，骨への荷 重負荷が減少した際の骨量維持には有効であろうと考 えられる。

しかしながら，本研究で，非荷重による骨量低下や 再荷重による骨量回復に対して，等尺性抵抗運動の効 果は認められなかった.この理由として, 第 1 に本研 究で負荷した運動条件が骨量増加を引き起こす十分な 条件を満たしていなかったことである，骨量増加は静 的負荷に比べ動的負荷で顕著であり ${ }^{24)}$ ，また同一の peak strain が生じる動的負荷では，力学的ストレス の加わる速度が速いほど骨量増加効果が高い2 ${ }^{25}$. 本研 究の等尺性抵抗運動では，持続的な体重支持と後肢筋 の収縮活動による力学的ストレスが骨に対して負荷さ れたと考えられ，短時間でインパクトとして力学的ス トレスが負荷される運動様式 ${ }^{13)}$ に比べ, 骨量維持・ 増加効果がみられなかったと考えられる。しかしなが ら, 本研究と同様の運動様式を用い, 負荷強度を高め た場合では，大腿骨の遠位 $1 / 5$ で非荷重による骨密度 低下が抑制されたこと到から，持続的な力学的ス卜 レスが加わる運動においても, 高強度の力学的ストレ ス負荷により，骨量低下を防止可能と考えられる。こ れは抵抗運動の骨量増加効果が低強度高頻度負荷に比 べ, 高強度低頻度負荷で顕著であり, 抵抗負荷の頻度 より強度が骨量増加に重要であることを示した Kerr ら 27)の成績により支持される。

第 2 にグルココルチコイドの影響である. 本研究 で, 非荷重ならびに再荷重期間中に抵抗運動を負荷し た動物では副腎重量の増大が認められた。 PattersonBuckendahl ら ${ }^{10)}$ は生理的範囲内でのストレス環境暴 露により, 本研究の抵抗運動負荷に伴う副腎重量増加 とほぼ同程度の副腎重量の増加を示し，それにより上
昇したコルチコステロン濃度は血清オステオカルシン 濃度の減少を引き起こすことを報告している。 Canalis $^{28)}$ はグルココルチコイドは骨量調節に関与す るホルモンの分泌動態やインスリン様成長因子などの 変化を招来し，骨量低下を引き起こすと論じている。 このようなグルココルチコイドによる骨量低下作用の 影響が抵抗運動の効果を相殺している可能性が考えら れる。

第 3 に体重減少の影響である。これは再荷重による 骨量回復に関するものであるが，回復運動群は回復対 照群や回復群に比べ体重の低值が認められたことか ら，飼育ケージ内活動における体重による荷重負荷の 低減が回復運動群の骨量回復を低下させたと考えられ る.これは言い換えると, 骨量の回復には抵抗運動負 荷に比べて，体重による荷重負荷の影響が大きいこと を示しているのかもしれない.

\section{おわりに}

本研究では，体重あたりの副腎重量は非荷重により 増加した。この増加は再荷重 3 週間後においても認め られており，また，運動負荷によりさらに増加した。 この結果は荷重条件の変化に対する骨応答にグルココ ルチコイドの影響が関与している可能性を間接的に示 唆している. 今後, 骨量低下やその回復ならびに運動 負荷の影響に関する研究において，骨に対する力学的 負荷の変化だけでなく, 生体ストレス反応との関連性 からの検討も必要であろう.

本研究の一部は平成 9 年度長寿科学総合研究「高齢者に 抢ける廃用症候群・過用症候・誤用症候の本態・予防・リ ハビリテーション」の分担研究として行われたことを記 し, 助成に対する感謝の意を表する.

\section{文献}

1) Globus RK, Bikle DD, Morey-Holton E : Effects of simulated weightlessness on bone mineral metabolism. Endocrinology 1984; 114 : 2264-2270

2) Leblanc AD, Schneider VS, Evans HJ, Engelbretson DA, Krebs JM: Bone mineral loss and recovery after 17 weeks of bed rest. J Bone Miner Res 1990 ; 5: $843-850$

3) Vico L. Bourrin S, Very JM, Radziszowska M, Collet $\mathrm{P}$, Alexandre $\mathrm{C}$ : Bone changes in 6-mo-old rats after head-down suspension and a reambulation period. J Appl Physiol 1995 ; 79 : 1426-1433

4) Bloomfield SA : Changes in musculoskeletal structure and function with prolonged bed rest. Med Sci 
Sports Exerc 1997 ; 29 : 197-206

5）七五三木聡, 柳田昌彦, 岡野浩哉, 山田めぐみ, 福井裕 子, 福村幸仁: 運動が閉経後の女性の骨量に及ぼす影 響. 体力研究 $1992 ; 80$ : 60-70

6) Frost HM : Bone "Mass" and the "Mechanostat" : a proposal. Anat Rec 1987 ; 219 : 1-9

7) Baldwin KM, White TP, Arnaud SB, Edgerton VR, Kraemer WJ, Kram R, Raab-Cullen D, Snow CM : Musculoskeletal adaptations to weightlessness and development of effective countermeasures. Med Sci Sports Exerc 1996; 10: 1247-1253

8）山内秀樹, 米本恭三: 廃用性筋萎縮に対する等尺性運 動の効果と加齢の影響. リ八医学 $1997 ; 34: 46-51$

9）山内秀樹, 米本恭三: 老齢期の廃用性萎縮筋の機能回 復に及ぼす運動負荷の影響：ヒラメ筋の変化. リ八医 学 $1997 ; 34: 212-217$

10) Patterson-Buckendahl PE, Grindeland RE, Shakes DC, Morey-Holton ER, Cann CE: Circulating osteocalcin in rats is inversely responsive to changes in corticosterone. Am J Physiol 1988; 254 : R 828-R 833

11) Vico L, Bourrin S, Novikov V, Very JM, Chappard $\mathrm{D}$, Alexandre C: Adaptation of bone cellular activities to tail suspension in rats. Cells Mater 1991; Suppl 1 : 143-150

12) Weinreb M, Rodan GA, Thompson DD : Osteopenia in the immobilized rat hind limb is associated with increased bone resorption and decreased bone formation. Bone $1989 ; 10$ : 187-194

13）殷 祥洙, 益子詔次, 山内秀樹, 猪飼哲夫, 米本恭三: 大 腿骨骨萎縮の予防に関する実験的研究. リ八医学 $2001 ; 38: 203-210$

14) Matsumoto $T$, Nakamura $K$, Kodama $Y$, Fuse $H$, Nakamura T, Fukumoto S: Effect of mechanical unloading and reloading on periosteal bone formation and gene expression in tail-suspended rapidly growing rats. Bone 1998 ; 22 : Suppl 89 S-93 S

15) Globus RK, Bikle DD, Morey-Holton E: The temporal response of bone to unloading. Endocrinology 1986; 118 : 733-742

16) Westerlind KC, Wronski TJ, Ritman EL, Luo ZP, An KN, Bell NH, Turner RT: Estrogen regulates the rate of bone turnover but bone balance in ovariectomized rats is modulated by prevailing mechanical strain. Proc Natl Acad Sci USA 1997 ; 94 : 4199-
4204

17) Sessions N De V, Halloran BP, Bikle DD, Wronski TJ, Cone CM, Morey-Holton E: Bone response to normal weight bearing after a period of skeletal unloading. Am J Physiol 1989 ; 257 : E 606-E 610

18) Thomaidis VT, Lindholm TS: The effect of remobilisation on the extremity of the adult rat after short-term immobilisation in a plaster cast. Acta Chir Scand Suppl 1976 ; 467 : 36-39

19) Mattsson S: The reversibility of disuse osteoporosis. Experimental studies in the adult rat. Acta Orthop Scand Suppl 1972; 144 : 1-135.

20) Tuukkanen J, Peng $Z$, Väänänen HK : The effect of training on recovery from immobilization-induced bone loss in rats. Acta Physiol Scand 1992; 145: 407-411

21) Young DR, Niklowitz WJ, Brown RJ, Jee WSS : Immobilization-associated osteoporosis in primates. Bone $1986 ; 7$ : 109-117

22) Rubin C, Turner AS, Mallinckrodt, C, Jerome C, Mcleod K, Bain S: Mechanical strain, induced noninvasively in the high-frequency domain, is anabolic to cancellous bone, but not cortical bone. Bone 2002 ; 30 : 445-452

23) Westerlind KC, Fluckey JD, Gordon SE, Kraemer WJ, Farrell PA, Turner RT: Effect of resistance exercise training on cortical and cancellous bone in mature male rats. J Appl Physiol 1998 ; 84 : 459-464

24) Lanyon LE, Rubin CT: Static vs dynamic loads as an influenceon bone remodelling. J Biomech 1984 ; 17 : 897-905

25）七五三木聡 : 運動と骨代謝. 体力科学 $1995 ； 44$ : 547554

26）山内秀樹, 遠藤千草, 益子詔次, 宮野佐年：後肢懸垂に 伴う大腿骨骨密度低下と荷重負荷の影響. 体力科学 $2001 ; \mathbf{5 0}: 671$ (抄)

27) Kerr D, Morton A, Dick I, Prince R: Exercise effects on bone mass in postmenopausal women are site-specific and load-dependent. J Bone Miner Res 1996 ; 11 : 218-225

28) Canalis $\mathrm{E}$ : Mechanisms of glucocorticoid action in bone: implications to glucocorticoid-induced osteoporosis. J Clin Endocr Metab 1996 ; 81 : 34413447 